\title{
Xanthine Oxidase during Human Fetal Development ${ }^{1}$
}

\author{
KIM VETTENRANTA AND KARI O. RAIVIO
}

Children's Hospital, University of Helsinki, SF-00290, Finland

\begin{abstract}
Through oxygen free radical production, xanthine oxidase (XOD, E.C.1.2.3.2) has been implicated in the pathogenesis of postischemic and hyperoxic tissue injuries among newborn. We measured the activity and evaluated the kinetic characteristics of XOD in human fetal liver, intestine, brain, and myocardium. Both the fetal liver and intestine contain a high XOD activity through gestation. The activity increases in the liver and decreases in the intestine with advancing gestation. The apparent $\mathrm{Km}$ for hypoxanthine is $4.8-5.5 \mu \mathrm{M}$ in the intestine throughout gestation and in the liver at term but higher than $30 \mu \mathrm{M}$ in the liver during the first half of pregnancy. The activity is undetectable both in the fetal brain and myocardium throughout gestation. Thus, XOD activity is present at least in the liver and intestine to account for the oxidation of hypoxanthine and xanthine. However, direct evidence for adenine nucleotide catabolism, followed by oxidation of the accumulated hypoxanthine during tissue reoxygenation in the human liver or intestine is not available. (Pediatr Res 27: 286-288, 1990)
\end{abstract}

\section{Abbreviations}

XOD, xanthine dehydrogenase/oxidase

HGPRT, hypoxanthine/guanine phosphoribosyltransferase

XOD (E.C. 1.2.1.37/1.2.3.2) catalyses the conversion of hypoxanthine to xanthine and on to uric acid. The enzyme exists in vivo predominantly as a $\mathrm{NAD}^{+}$-dependent dehydrogenase but is converted to an oxygen-dependent oxidase reversibly by sulfhydryl oxidation or irreversibly by proteolysis. The human enzyme has an apparent $\mathrm{Km}$ of about $10-11 \mu \mathrm{M}$ for hypoxanthine in the liver and jejunum, where the highest enzyme activity is found $(1-8)$.

In the oxidation of hypoxanthine and xanthine, superoxide radicals are generated. These, and secondary radicals derived from them, are capable of initiating chain-reactions resulting in cell injury through lipid peroxidation, protein damage, etc. (9). XOD has been postulated to be the major source of superoxide radicals during reoxygenation of postischemic tissues. During ischemia, hypoxanthine accumulates as a result of adenine nucleotide catabolism, and simultaneously xanthine dehydrogenase is converted into oxidase $(10)$. When oxygen is reintroduced to the tissue during postischemic reperfusion, hypoxanthine is oxidized to xanthine and uric acid by the oxidase. The result is a

Received August 30, 1989; accepted October 30, 1989.

Correspondence and reprint requests Kim Vettenranta, M.D., Children's Hospital, University of Helsinki, Stenbäckinkatu 11, SF-00290 Helsinki, Finland.

Supported by the Sigrid Juselius Foundation, the Foundation for Pediatric Research, and the Finnish Cultural Foundation.

' Presented in part at the annual meeting of the European Society for Pediatric Research in Krakow, June 11-14, 1989. burst of superoxide radical and hydrogen peroxide production, and possibly tissue injury $(2,5,11)$. This mechanism has been strongly implicated in the pathogenesis of ischemia-reperfusion injury of the small intestine (12-15).

Tissue damage in the CNS, lungs, myocardium, liver, and intestine is common among extremely premature infants. A role for the hypoxanthine-XOD system in the pathogenesis of several prematurity-related problems, including bronchopulmonary dysplasia, necrotizing enterocolitis, and retinopathy of prematurity has been suggested $(16,17)$. Yet, evidence for this hypothesis is mostly circumstantial, and essential data concerning the activity of XOD in fetal tissues as well as its kinetic characteristics during fetal development are lacking.

The aim of our study was to measure the activity and substrate affinity of XOD in the liver, brain, myocardium, and intestine during human fetal development.

\section{MATERIALS AND METHODS}

$\left[8-{ }^{14} \mathrm{C}\right]$ hypoxanthine was obtained from Amersham International, Little Chalfont, UK; cellulose thin-layer plates from Eastman Kodak, Rochester, NY; NAD ${ }^{+}$from Boehringer Mannheim, Mannheim, FRG; pyruvic acid and lactic dehydrogenase from Sigma Chemical, St. Louis, MO; and Aquasol from New England Nuclear, Boston, MA.

Fetal tissues were obtained from elective terminations, and neonatal tissues from necropsies. The fetal samples were taken within $2 \mathrm{~h}$ after termination, and the neonatal samples within $20 \mathrm{~h}$ after death. The material consisted of samples from 45 fetuses (10-20 gestational wk), nine preterm babies (25-28 wk), and 15 term babies. The intestinal samples were taken from proximal jejunum. None of the neonates had signs of necrotizing enterocolitis or any other pathologic process of the intestine. All samples were quickly frozen and stored at $-70^{\circ} \mathrm{C}$. No decrease in enzyme activity took place under these conditions.

The tissue samples were homogenized with a Teflon pestle in 5 vol of $100 \mathrm{mM}$ Tris- $\mathrm{HCl}$, pH 8.0 , containing $0.02 \% \beta$-mercaptoethanol, and sonicated for $15 \mathrm{~s}$ at $50 \mathrm{~W}$ three times on ice. The sonicates were then centrifuged at $10000 \times g$ for $20 \mathrm{~min}$ at $+4^{\circ} \mathrm{C}$, and the supernatants dialyzed against the homogenization buffer at $+4^{\circ} \mathrm{C}$ for $17 \mathrm{~h}$.

The assay mixture contained $160 \mu \mathrm{M}\left[8-{ }^{14} \mathrm{C}\right]$ hypoxanthine (sp act $50-60 \mathrm{mCi} / \mathrm{mmol}$ ), $5 \mathrm{mM} \mathrm{MgCl}, 0.3 \mathrm{mM} \mathrm{NAD}^{+}, 2 \mathrm{mM}$ pyruvic acid, and $18 \mathrm{IU}$ of lactic dehydrogenase (18), and $25 \mu \mathrm{L}$ of sample in a total volume of $50 \mu \mathrm{L}$. The incubation was carried out at $+37^{\circ} \mathrm{C}$ in air on an oscillating water bath, and terminated with $5 \mu \mathrm{L}$ of $4.2 \mathrm{~N}$ perchloric acid on ice. The mixture was subsequently neutralized with cold $4.42 \mathrm{~N} \mathrm{KOH}$, and centrifuged at $800 \times g$ for $10 \mathrm{~min}$. A $10-\mu \mathrm{L}$ aliquot of the supernatant was spotted on a cellulose chromatogram sheet, and developed in 95\% ethanol: $1 \mathrm{M}$ ammonium acetate, $\mathrm{pH} 7.5$ (75:30) for about $2.5 \mathrm{~h}$. The spots containing hypoxanthine and xanthine plus uric acid were scraped off and counted in Aquasol using liquid scintillation. The production of xanthine and uric acid from hypoxanthine was linear for at least $30 \mathrm{~min}$. The kinetic param- 
eters were assayed at $+37^{\circ} \mathrm{C}$ and $\mathrm{pH} 8.0$ in the presence of $4.1-$ $79.5 \mu \mathrm{M}\left[8-{ }^{14} \mathrm{C}\right]$ hypoxanthine $(3,19,20)$.

Possible changes in the enzyme activity during the first $24 \mathrm{~h}$ after death were evaluated using samples of rabbit liver, and identical storage conditions.

Blank values, obtained by adding perchloric acid and placing the tubes on ice before adding the isotope, were subtracted from the corresponding experimental values in all experiments.

All assays were performed in duplicate with three time points within the linear range of each assay. The $\mathrm{Km}$ and $\mathrm{V}_{\max }$ values were estimated from double-reciprocal plots. Protein was measured according to Peterson (21). In statistical analysis, Student's $t$ test (two-sided) was used. Results are given as mean $+\mathrm{SD}$.

\section{RESULTS}

The activity of XOD increased significantly in the fetal liver (Fig. $1 A$ ) but decreased in the intestine (Fig. $1 B$ ) toward term. The intestinal activity exceeded that in the liver 4- to 37 -fold during the first two trimesters but settled at a similar level near term.

The hepatic enzyme had an apparent $\mathrm{Km}$ of more than 30 $\mu \mathrm{M}\left(\mathrm{V}_{\max } 0.14 \pm 0.10 \mathrm{nmol} / \mathrm{mg}\right.$ protein $\left./ \mathrm{min}\right)$ for hypoxanthine during the first half of pregnancy but less than $6 \mu \mathrm{M}\left(\mathrm{V}_{\max } 1.6 \pm\right.$ $0.3 \mathrm{nmol} / \mathrm{mg}$ protein/min) at term (Fig. 2). The intestinal enzyme had a $\mathrm{Km}$ of $4.8 \pm 1.6 \mu \mathrm{M}\left(\mathrm{V}_{\max } 3.3 \pm 1.4 \mathrm{nmol} / \mathrm{mg}\right.$ protein/min) for hypoxanthine throughout gestation.

In both the fetal brain and myocardium XOD activity was less than the limit of detection of the assay $(0.02 \mathrm{nmol} / \mathrm{mg}$ protein/ min) throughout gestation. The enzyme activity did not change in samples of rabbit liver during storage at $+4^{\circ} \mathrm{C}$ for up to $24 \mathrm{~h}$ after death.

\section{DISCUSSION}

Although the conversion of xanthine dehydrogenase to oxidase most likely was completed in our samples before assay, we decided to measure the combined activity, which does not seem to change during ischemia (10).

Even though the activity of XOD in the fetal liver appears to increase with gestation, it remains roughly of the same magnitude as that reported in adult liver $(4,22)$. The kinetic parameters of fetal hepatic XOD also appear to change. Its $\mathrm{Km}$ for hypoxanthine decreases as a function of gestational age, and at term is of the same magnitude as that in adult liver (3).

In the human fetal intestine, the activity of XOD appears to decrease from a high level during early fetal life to adult levels (4) by term, and its $\mathrm{Km}$ for hypoxanthine is of the same magnitude as that in the adult intestine (3). Both the fetal hepatic and intestinal activities exceed that of the human trophoblast throughout gestation (19).

The kinetic characteristics of XOD, and the other major cytoplasmic hypoxanthine-metabolizing enzyme, HGPRT (E.C. 2.4.2.8), determine the fate of intracellular hypoxanthine. In adult human tissues, both HGPRT and XOD appear to have a $\mathrm{Km}$ of about $4-11 \mu \mathrm{M}$ for hypoxanthine $(3,23)$. The $\mathrm{Km}$ for hypoxanthine of hepatic HGPRT (about $59 \mu \mathrm{M}$ ) (Vettenranta $\mathrm{K}$, Raivio KO, unpublished data) seems to be of the same
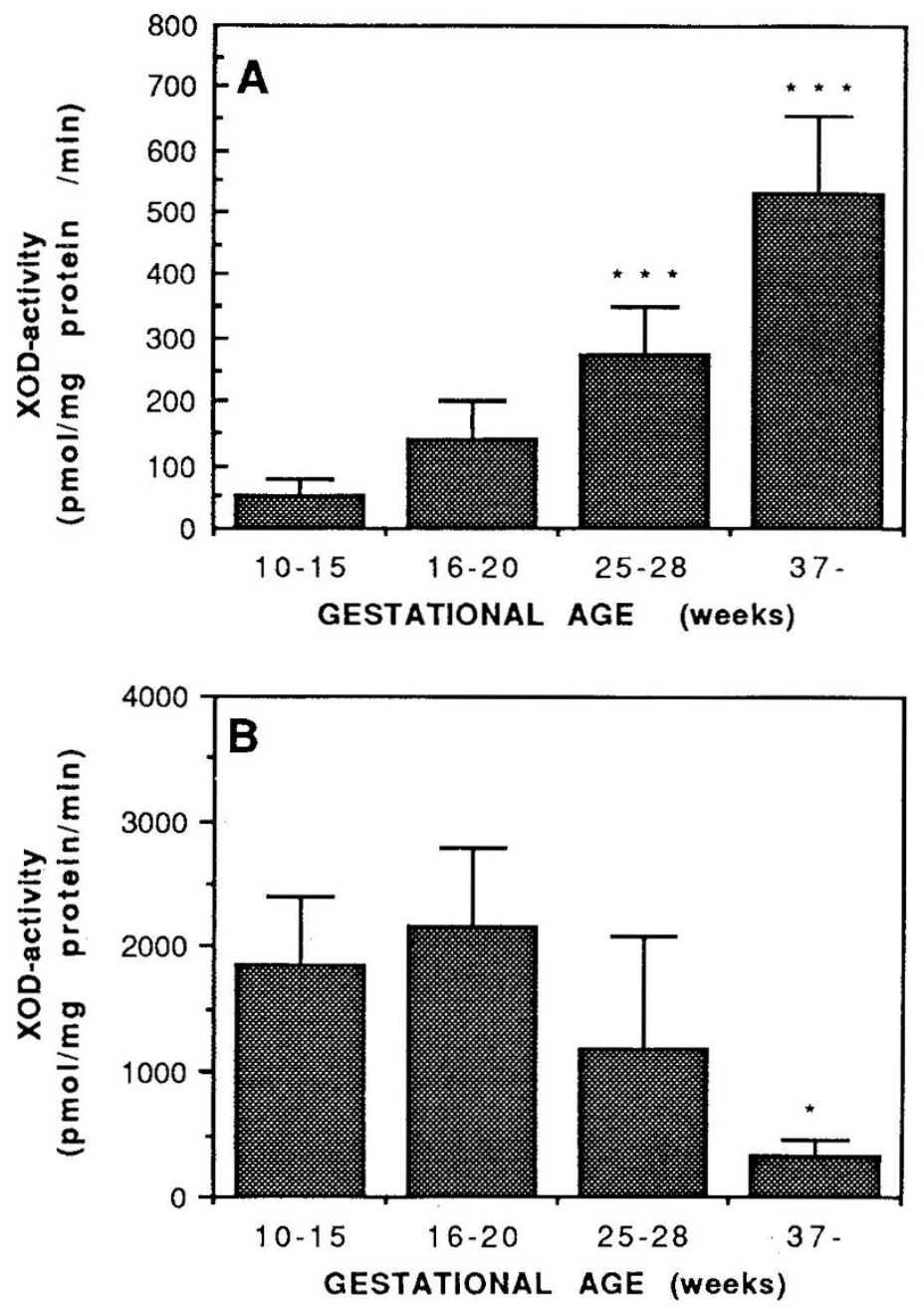

Fig. 1. The apparent activity of xanthine dehydrogenase/oxidase in the human fetal liver $(A)$ and intestine $(B)$ as a function of gestational age. *** indicates $p<0.001$ and ${ }^{*} p<0.05$ versus values of the preceding gestational age group. 


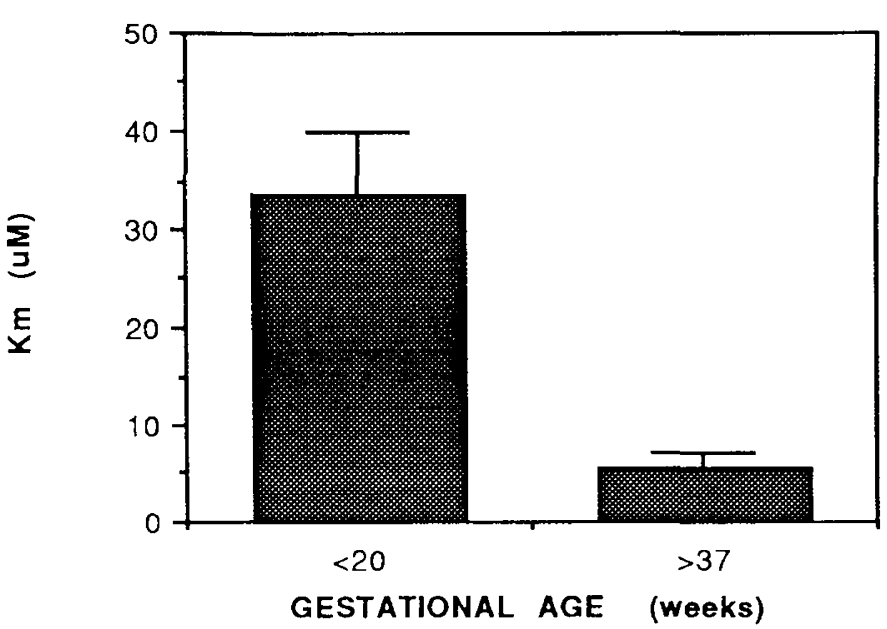

Fig. 2. The apparent $\mathrm{Km}$ of the human fetal hepatic XOD as a function of gestational age.

magnitude as that of XOD during early fetal life but substantially higher near term. The hepatic activities of HGPRT (Vettenranta $\mathrm{K}$, Raivio $\mathrm{KO}$, unpublished data) and XOD seem to increase in parallel with advancing gestation. Thus, in the human fetal liver near term, the capacity to metabolize hypoxanthine appears high and its catabolism at low concentrations kinetically favored over reutilization.

The gestational change observed in the kinetic characteristics of hepatic XOD might well be explained by different isoforms of the enzyme. However, any data on dissimilar isoforms appearing in adult or fetal tissues have not been reported. In addition, even though the effect of several inhibitors on XOD activity has been demonstrated, their physiologic role as well as possible changes in that role with gestation also remain to be established (4).

Conflicting data on the activity of XOD in the human adult brain have been reported $(22,25)$. Our data appear to agree with those of Krenitsky and co-workers (25) in suggesting a low XOD activity in the human cerebrum.

Animal experiments have provided evidence suggesting a role for XOD in the pathogenesis of postischemic myocardial injury and dysfunction (26-28). Differences in the myocardial activity of XOD between various mammalian species (29) have, however, prompted studies on its role in the pathogenesis of human myocardial injury. Our data on the human fetal heart are in agreement with those of the majority of previous investigators (30-34), who could not find any or only trace amounts of XOD activity in adult human myocardium. Although Wajner and Harkness (22) recently reported high XOD activity in adult human heart, it thus appears more likely that XOD is not a significant source of oxygen free radicals in the human myocardium.

Although our data do not contradict the concept of XOD as a source of oxygen-free radicals in the neonatal postischemic liver (35) or intestine (12) by verifying the presence of XOD activity in these tissues throughout gestation, conclusions concerning in vivo mechanisms are difficult to draw from studies using disrupted cells. Consequently, the putative role of XOD in neonatal postischemic tissue injuries as well as the pathways of fetal hepatic and intestinal hypoxanthine catabolism, essentially remain to be further studied using, e.g. cultured cells and/or perfusion of the liver and intestine.

Acknowledgments. The skillfull technical assistance of Sinikka Tsupari and Ritva Löfman is gratefully acknowledged. We also thank Dr. Timo Otonkoski for valuable assistance in the collection of the samples.

\section{REFERENCES}

1. Battelli MG 1980 Enzymic conversion of rat liver xanthine oxidase from dehydrogenase (D form) to oxidase (O form). FEBS Lett 113:47-51
2. McKelvey TG, Höllwarth ME, Granger DN, Engerson TD, Landler U, Jones HP 1988 Mechanisms of conversion of xanthine dehydrogenase to xanthine oxidase in ischemic rat liver and kidney. Am J Physiol 254:G753-G760

3. Mousson B, Desjacques P, Baltassat $P 1983$ Measurement of xanthine oxidase activity in some human tissues. Enzyme 29:32-43

4. Parks DA, Granger DN 1986 Xanthine oxidase: biochemistry, distribution, and physiology. Acta Physiol Scand [Suppl] 548:87-99

5. Parks DA, Williams TK, Beckman JS 1988 Conversion of xanthine dehydrogenase to oxidase in ischemic rat intestine: a re-evaluation. Am J Physiol 254:G768-G774

6. Schoutsen B, De Jong JW, Harmsen E, De Tombe PP, Achterberg PW 1983 Myocardial xanthine oxidase/dehydrogenase. Biochim Biophys Acta 762:519-524

7. Stirpe F, Della Corte E 1969 The regulation of rat liver xanthine oxidase. J Biol Chem 244:3855-3863

8. Waud WR, Rajagopalan KV 1976 Purification and properties of the NAD ${ }^{+}$ dependent (type D) and $\mathrm{O}_{2}$-dependent (type $\mathrm{O}$ ) forms of rat liver xanthine dehydrogenase. Arch Biochem Biophys 172:354-364

9. Weiss SJ 1986 Oxygen, ischemia and inflammation. Acta Physiol Scand [Suppl] 548:9-37

10. Engerson TD, McKelvey TG, Rhyne DB, Boggio EB, Snyder SJ, Jones HP 1987 Conversion of xanthine dehydrogenase to oxidase in ischemic rat tissues. J Clin Invest 79:1564-1570

11. McCord JM 1985 Oxygen-derived free radicals in post-ischemic tissue injury. N Engl J Med 312:159-163

12. Granger DN, Höllwarth ME, Parks DE 1986 Ischemia-reperfusion injury: role of oxygen-derived free radicals. Acta Physiol Scand [Suppl] 548:47-63

13. Granger DN, McCord JM, Parks DA, Höllwarth ME 1986 Xanthine oxidase inhibitors attenuate ischemia-induced vascular permeability changes in the cat intestine. Gastroenterology 90:80-84

14. Grisham MB, Anzueto Hernandez L, Granger DN 1986 Xanthine oxidase and neutrophil infiltration in intestinal ischemia. Am J Physiol 251:G567-G574

15. Granger DN 1988 Role of xanthine oxidase and granulocytes in ischemiareperfusion injury. Am J Physiol 255:H1269-H1275

16. Saugstad OD 1985 Oxygen radicals and pulmonary damage. Pediatr Pulmonol 1:167-175

17. Saugstad OD 1988 Hypoxanthine as an indicator of hypoxia: its role in health and disease through free radical production. Pediatr Res 23:143-150

18. Della Corte E, Stirpe F 1970 The regulation of xanthine oxidase. Biochem J 117:97-100

19. Vettenranta K, Raivio KO 1988 Activities of key enzymes of purine degradation and re-utilization in human trophoblastic cells. Placenta 9:27-37

20. Akaoka I, Nishizawa T, Nishida Y 1975 Determination of hypoxanthine and xanthine in plasma separated by thin-layer chromatography. Biochem Med $14: 285-289$

21. Peterson GL 1977 A simplification of the protein assay method of Lowry et al., which is more generally applicable. Anal Biochem 83:346-356

22. Wajner M, Harkness RA 1989 Distribution of xanthine dehydrogenase and oxidase activities in human and rabbit tissues. Biochem Biophys Acta 991:79-84

23. Raivio KO, Seegmiller JE 1970 The role of phosphoribosyl-transferases in purine metabolism. In: Horecker BL, Stadtman ER (eds) Current Topics in Cellular Regulation, Vol 2. Academic Press, New York, pp 201-225

24. Deleted in proof

25. Krenitsky TA, Tuttle JV, Cattau Jr EL, Wang P 1974 A comparison of the distribution and electron acceptor specificities of xanthine oxidase and aldehyde oxidase. Comp Biochem Physiol 49B:687-703

26. Chambers DE, Parks DA, Patterson G, Roy R, McCord JM, Yoshida S, Parmley LF, Downey JM 1985 Xanthine oxidase as a source of free radical damage in myocardial ischemia. $\mathrm{J}$ Mol Cell Cardiol 17:145-152

27. Charlat ML, O'Neill PG, Egan JM, Abernethy DR, Michael LH, Myers ML, Roberts R, Bolli R 1987 Evidence for a pathogenetic role of xanthine oxidase in the "stunned" myocardium. Am J Physiol 252:H566-H577

28. Hearse DJ, Manning AS, Downey JM, Yellon DM 1986 Xanthine oxidase: critical mediator of myocardial injury during ischemia and reperfusion? Acta Physiol Scand [Suppl] 548:65-78

29. Grum CM, Ketai LH, Myers CL, Shlafer M 1987 Purine efflux after cardiac ischemia: relevance to allopurinol cardioprotection. Am J Physiol 252:H368 H373

30. Downey JM, Hearse DJ, Yellon DM 1988 The role of xanthine oxidase during myocardial ischemia in several species including man. J Mol Cell Cardiol 20 (suppl II):55-63

31. Eddy LJ, Stewart JR, Jones HP, Engerson TD, McCord JM, Downey JM 1987 Free radical-producing enzyme, xanthine oxidase, is undetectable in human hearts. Am J Physiol 253:H709-H711

32. Ramboer CRH 1969 A sensitive and nonradioactive assay for serum and tissue xanthine oxidase. J Lab Clin Med 74:828-835

33. Watts RWE, Watts JEM, Seegmiller JE 1965 Xanthine oxidase activity in human tissues and its inhibition by allopurinol (4-hydroxypyrazolo 3,4 d)pyrimidine). J Lab Clin Med 66:688-697

34. Grum CM, Gallagher KP, Kirsh MM, Shlafer M 1989 Absence of detectable xanthine oxidase in human myocardium. J Mol Cell Cardiol 21:263-267

35. Adkison D, Höllwarth ME, Benoit JN, Parks DA, McCord JM, Granger DN 1986 Role of free radicals in ischemia-reperfusion injury to the liver. Acta Physiol Scand [Suppl] 548:101-107 